\title{
Determination of Junior High School Location Through Geographic Information System Utilization
}

\author{
Opilona Badriyah \\ Postgraduate of Geography Education, Universitas Pendidikan Indonesia \\ Email: opilonabadriyah11@gmail.com
}

\begin{abstract}
Geographic Information Systems (GIS) is a management tool in the form of computer-assisted information related to the system's mapping and analysis of all occurences on earth. In education, GIS can be used to determine the location of the new school. The purpose of writing this article is to explain the importance of GIS in determining the location of education. The object of study is the equity and expansion of education access, in the form of determining the location of new schools. The method of writing this article was using the relevant literature analysis. Conclusion of this article is for equity and justice of public access in obtaining education service, determination of new school location needs to use Geographic Information System.
\end{abstract}

Keywords: School Location Determination, GIS Utilization

\section{Introduction}

Education aspect is one of important element in human resource management and development. Therefore, human development would be in line with the education they got from an early age, starting with basic education to upper secondary education or even higher education. Law No. 20 of 2003 on the National Education System is the legal basis for the implementation and reformation of national education system. The law contains vision, mission, functions and purposes of national education, as well as national education development strategies to achieve a good quality education, relevant with the needs of community and competitive in global life. So, it is necessary to have a good planning and management of education development for every administrator and implementer of education. National standards of education facilities at the primary and secondary levels are contained in the Ministry of National Education Regulation No. 24 of 2007 on Standards of Facilities and Infrastructure for Elementary, Junior High School, Senior High School or equivalent. The regulations stipulate the education unit, land, buildings, as well as the provision of facilities and infrastructure. With the national standard, the government is required to increase the allocation of funds so that the minimum standard of facilities and infrastructure for elementary, junior high school, or equivalent can be fulfilled.

The challenges that schools has deal with as one part of the city space were more severe. On one hand, the quantity of schools must answer the ever-growing needs of community and the quality of schools are required to facilitate learning activities with the more increasing standarts. On the other hand, schools must "compete" with various interests and other activities in land use. One of the challenges in education is the distribution pattern in the form of the gap (which is large) between regions in the ratio of the number of school-age population by the number of school units, the imbalance between capacity and needs, as well as the availability of land for development and construction of schools. In 2017, for Admission of New Students (PPDB) government began implementing a zoning system at each level of education. The system is set in Permendikbud No. 17 of 2017 No. 17 of 2017 on Admission of New Students at Kindergarten, Elementary School, Junior High School, Senior High School, Vocational High School, or other forms 
that equivalent. With applying the zoning system, school that organized by local government must accept prospective students who live in the nearby zone radius of the school. Lack of preparation of each region to the new regulations, resulting in a lot of prospective students does not accepted by the nearest public school in their territory. Because of there are some prospective students that their home and school was relatively distant, while in their territory there were only a few schools. In addition, there are many students who can not choose or being accepted in favorite school that have choosen by them due to the zoning system. Application of zoning system that does not consider the number of school-age children and the number of school units in an area, resulting in school-age children were not accommodated in the school. So the new schools is needed, because in the territory there are only a few schools. Determining the location of new school units are expected to be one of the effective solutions in the distribution of education infrastructure.

School in this discussion, is limited to junior high schools, considering the establishment of 9-year compulsory education program should begin to be implemented in order to meet the demands of time. Where every citizen is entitled to get a minimum education at the level of primary education, namely elementary school up to junior high school. According to the nine years compulsory education program, junior high school is an obligation for every Indonesian citizen who has graduated from elementary school or equivalent with the age limit of 13-15 years to attend junior high school or equivalent to end (Kamsori, 2007). As in the Law No.20 of 2003 on National Education System CHAPTER IV article 6 paragraph 1 stated that "Every citizen aged 7-15 years must follow primary education". Therefore, as the consequences it is necessary for the role of central government, local government, parents, and students themselves. The lack of availability of school facilities makes it difficult to accommodate the enthusiasm and needs of people who want to go to high school. Therefore, to realizing the program, geographic planning model of facilities or education facilities using Geographic Information System (GIS) are required. Geographic Information Systems is a system that can be used to input, store, check, integrate, manipulate, analyze, and display the data which has space references or locations on the surface of the earth (Setiawan, 2010).

Computer-based information system that combines elements of the map (geographical) and designed to receive, process, manipulate, the information about the map (the attribute data) analysis, modeling and display spatial data to complete the planning, process and investigate the problem including information about education covering the distribution of schools and geographical potential for school construction with reference to various supporting parameters. Geographic Information Systems (GIS) have important role in education, especially in knowing which areas that does not served a good education to be given a solution, so that the planned programs can be implemented and be right on target.

\section{Method}

Research has not been conducted for this article, so it is only an analysis of literature studies as a reinforcement to discuss the problem. Research method that can be used to determine the location of the construction of school buildings is descriptive quantitative method. Where data collecting technique includes observation, documentation, and interviews. After that, the data would be analyzed with quantitative description analysis and GIS, such as scoring and buffering in order to know the exact location for school building constructions (Ahmadi and Indrayati, 2014). Determination of the location of school building must be strategic and reachable by the population that their territory does not have the education facilities yet, so the application of zoning system on New Student Acceptance could be work maximally. 


\section{Results and Discussion}

\section{The Role of Education in Development}

Mentioned in the Law of 1945, that one of Indonesian state government purposes was to educate the nation (education), it implicitly explains the importance of the role of education in the context of the educating life of the nation, which is one of the main goals of Indonesian state. Education also has an important meaning for humans, because with an education can provide knowledge, skills and values in society. The role of education also stimulates and accompanies the changes and developments that exist in society (Tim IKIP, 1980).

In order to improve the quality of population, the government needs to undertaking the quality of education and health of population. The basic improvement of education quality that can be done by the government is to improve the quality and quantity of educational facilities such as school buildings. Role of education can provide reinforcement on one side, namely the improvement of human resources. This directly or indirectly, will provide reinforcement to the other side. Strengthening the education, for example by improving the system and streamlining learning activities by optimizing the function of educational facilities and infrastructure, will add the success in building community. On the other hand, strengthening the community by well-managing the owned potential, will increase the success of the function and role of education generally. The implication, reinforcement on both sides simultaneously will provide optimal results, both in terms of the role of education and sustainable community development.

\section{Standards of Education Facilities and Infrastructure}

Facilities is the equipment that required to organize a movable learning covers meubiler, libraries meubiler, textbooks, reference books, teaching aids, laboratory equipment and practice tools. While the infrastructure is the basic facilities that needed to carry out the functions of educational units that include the availability of land, buildings, classrooms, libraries, laboratories, leadership room, teachers room, administrative space, places of worship, counseling room, UKS space, student organization space, latrines, warehouses, circulation spaces and play/sport areas. (Permendikbud Nasional, No. 24 of 2007). Basic and Secondary Education Facilities and Infrastructure Standards by Ministry of National Education RI includes infrastructure for SD/MI, SMP/MTs, and SMA/MA. (Permendikbud Nasional, No. 24 of 2007) The standard of educational facilities in this study is limited only to SMP/MTs and will only be reviewing the educational units are in it is set on the number of study groups, the maximum number of served population, and the service area of an educational facility. Educational unit standard of SMP/MTs, are.

1. One SMP/MTs have minimum of 3 study groups and maximum of 24 study groups.

2. One SMP/MTs with three study groups are serving maximum 2000 peoples. To serve population with more than 2000 people, it has to adding study groups in the existed school, and if study groups were more than 24 , it has to build a new SMP/MTs.

3. One sub-district were served by minimum one SMP/MTs that can accommodated all of SD/MI graduates in that sub-district.

4. A group of permanent and isolated settlements with a population of more than 1000 people served by one SMP/MTs within the distance for students walking a maximum of $6 \mathrm{~km}$ through non-hazardous path.

Based on education facilities standard by Ministry of Education and Culture, there were some criteria of education facilities location for Middle School, which are. 
1. Easy to reach by every parts of sub-district;

2. Can be reached by students in less of walking for 45 minutes;

3. Distant from the center of crowd (shops, offices, industries.

Planning for school buildings by Ministry of Public Works, considering these aspects.

1. Public high school facilities are planned with urban development trends, municipal master plans, and must be approved by the local government.

2. The density and population potency ( $\%$ of school-aged population) has to support education activities so that besides it can determine school location, it will aso determine the types of school.

3. Reach-radius are determined by mileages, age factor, students physical ability, and transportation facilities. Reach-radius from high school is set at a maximum of $5 \mathrm{~km}$ or 1 hour drive (on foot). Locations should be avoided from high-density traffic to avoid accidents and traffic jam.

4. Environmental conditions greatly determine the physical location of the school. The environment is distinguished in natural environment, namely: geography, topography, climatology, flora and fauna, and artificial environments such as buildings and society (socio-cultural and socioeconomic). Requirement of the location of school buildings on the environment is achieving: comfort, tranquility, health, and security.

It can be concluded that in determining and planning the construction of school buildings need to consider the accessibility (distance and travel time), the distribution of schools, population conditions, and environmental conditions.

\section{Location Concepts}

Location theory is a science that investigates spatial (spatial order) of economic activity, or the science that investigates geographoc allocation of sources that potential, as well as its relation with or influence on the existence of various activities both of economic and social (Tarin, 2006) . The location theory as a science that examines spatial geographically possesses the linkage or influence with the place of economic and social activity. Thus location theory can be used in assessing a location as an economic activity as well as a place of social services such as the location of education.

\section{Factors in Determining School Location}

The determination of the location of a school construction is prioritized to pay attention to some factors such as accessibility factor, environmental factor, population factor, and capacity factor (distribution pattern) (Aulia, et al., Year). First,accessibility is one of the factors that influence whether a site can be interesting to visit or not. The level of accessibility is the level of ease in reaching and heading towards a location in from the other locations around it (Tarigan, 2006). According to Tarigan, the accessibility level is influenced by distance, the condition of the transportation infrastructure, the availability of various connecting facilities including its frequency and the level of security and convenience to pass through the path. In the analysis of an existing city or town plan, it is known as standard for location requirement or standard of distance (Jayadinata, 1999) as shown in Table 1 below. 
Table 1. Standard of Distance in The City

\begin{tabular}{|l|l|l|}
\hline No & Infrastructures & $\begin{array}{l}\text { Distance from Place } \\
\text { (By walking) }\end{array}$ \\
\hline 1 & Workplace Center & 20 minutes -30 minutes \\
\hline 2 & City Center (Market, etc.) & 30 minutes -45 minutes \\
\hline 3 & Local Market & $3 / 4 \mathrm{~km}$ or 10 minutes \\
\hline 4 & Elementary School (SD) & $3 / 4 \mathrm{~km}$ or 10 minutes \\
\hline 5 & Junior High School (SMP) & $11 / 2 \mathrm{~km}$ or 20 minutes \\
\hline 6 & Senior High School (SMA) & 20 or 30 minutes \\
\hline 7 & Playground or Parks & $3 / 4 \mathrm{~km}$ or 20 minutes \\
\hline 8 & Sports Venue (Recreation) & $1 \frac{1}{2} \mathrm{~km}$ or 20 minutes \\
\hline 9 & Public Parks (Conservation, Zoo, etc.) & 30 to 60 minutes \\
\hline
\end{tabular}

Source: Chapin in Jayadinata (1999).

Accessibility (ease of mileage) will affect the affordability of a location, as it relates to the ease of getting to that location from various locations around it or the other areas. So it can be said that accessibility becomes the main attraction of a location. It was also mentioned that one of the criteria in choosing the location is a good connecting level which are the availability of public transportation, road network, departure frequency and distance. This accessibility factor is analyzed based on the nearest area that is accessible according to the road network map based on the minimum distance or time constraint between house and school. Maximum distance of school residence based on the prevailing standard in Indonesia with no differentiation between selected transportation and road conditions. Indicators that determine this accessibility are: proximity of location with transportation network and proximity of location with city center. (Wimardana et al., 2014). The second factor is the environment where it became one of the factors that influence several aspects such as the formation and development of individual behavior in terms of physical and social. Environmental factors consists of the cleanliness and comfort of a site. (wimardana, et al., 2014). Cleanliness is shown with an education location that clean, pollution-free, whereas the comfort shown with educational facilities that free from noise and crowds. In addition, the environmental factors here also consists of the security and serenity of a location. Security is shown with the location of educational facilities that are safe from outside interference (Aulia, without years). Third, the population factors, where in determining education location should be based on population numbers by school-aged so that in determining the location of the school can be precisely targeted. Educational facilities are closely linked to social facilities and basically related to the needs of community and are giving satisfaction for community. Therefore, the existence of educational facilities should be cultivated to fulfill the needs of residents in residential neighborhood to achieve prosperity for the community. Fourth, is capacity factor (distribution pattern) that intended to analyze the distribution of schools by looking at suitability of the supply-demand schools. Projection of population in the future in order to determine the required amount of SMP facilities will also be conducted. Supply (the number of school capacity) were analyzed by standard minimum area of schools, school areas per student, number of students per class, as well as the number of students per teacher, while demand (needs) were analyzed by high school-age population that is 16-18 years old. The analysis of this distribution pattern was conducted to minimize the interregional gap for the ratio of the school-aged population with the number of schools, the imbalance between capacity and needs, and the limited land for school for development and construction. Legal protection for this distribution pattern is also regulated in the national standard of educational facilities and infrastructures which contained in Permendiknas Number 24 Year 2007 regarding Standard of Facilities and Infrastructure for Elementary, Junior High School, Senior High School or equivalent. 


\section{GIS Application in Education Location Determination}

Geographic Information Systems (Geographic Information System / GIS) is a computer-based information systems that used to process and store data or geographic information (Aronoff, 1989). In general, Geographic Information Systems (GIS) or Mapping and Geography-based Information System is an management tools in the computer-assisted information that closely linked with system of mapping and analysis of all things and occurrences on earth. GIS technology integrates the operations of database-based data processing which commonly used today, such as retrieval of data based on the needs, as well as statistical analysis using a typical visualization as well as the benefits that were able to be offered through geographic analysis through images of the maps.

\section{Role of GIS in Education}

Education has to take the role more in establishing all of human potential in order to be a subject that develops optimally and beneficial for community and in national development. Yousman (in Setiawan, 2010) explains that in the field of education, GIS is used to determines school locations, create educational information systems, and as a tool for understanding geographical learning. While GIS role in education according to Prayoga (Pranata, 2014) is as follows.

Equity and Expansion of Education Access

This role can be performed in the presence of school mapping that if synergized with GIS utilization, will obtained a system that is able to record any area or region that has not been well-served in education and given the solutions (i.e.: give block grant). So that the planned programs can be right on target. In addition, the determination of the location of new schools can be done by combining some data (school-aged population) with maps (road network maps, land use maps, maps of industrial estates) so that a comprehensive education plan can be obtained. Function of overlay, query, buffer that owned by GIS will be very helpful in this process.

\section{Education Planning that Synchronized with Potential and Area Development}

Using GIS program application, it can determine local potential that can be developed by a region. And to provide human resources in charge of developing the region, the development of education must be adjusted to the potential of the region so that the resulting output can be utilized to cultivate the potential

\section{Education Evaluation and Monitoring Activities}

With GIS, evaluation and monitoring of education is very easy to do. (such as: Division of rayonization to facilitate the supervision or even distribution of educational services so that there is no gap between one area with another).

Supporter of the implementation of education autonomy activities in each region in accordance with the characteristics and local potential

With the enacted of region autonomy law, the implementation of GIS program will provides a way to local government to be creative in accordance with local needs along with its education characteristics.

\section{Supporter of implementation of Law No. 20 Year 2003 (Law of National Education System)}

Related with the extent of the territory of Indonesia, then using GIS will be able to support the implementation of national education system, which means that education can be implemented not only with formal education, but also implemented outside of the school or other places that are considered to be reached by all layers of society in a region, suitable with the characteristics of the region. 
Place to Cultivate The Insight of Nationality Since Early Age

With the introduction of GIS in the world of education whether it can be the early form of geography lessons, it can be used as a place in cultivating insight of nationality for every citizen from an early age through all levels and existed educational path.

GIS has an important role in the field of education, especially in the distribution and expansion of access to education. With GIS application, it will be observed which areas that are not well-served by education and given a solution, so that the planned programs can be implemented and can be right on target. Implementation of Zoning System on New Student Acceptance has weaknesses, one of them is not using the education map in the program. If only there is a map and then use the help of GIS applications, then there will be no more errors in the application of zonation system on the PPDB. However, basically in determining the location of schools as a result of zoning system using GIS still has weaknesses, one of them is a social problem that will arise in society. In its application required a mature readiness in the planning, so the problems that will arise can be minimized.

\section{Determination The Point of New School Units Location}

There are several standards that must be met in determining the locations of the new school unit, one of them is accessibility factor, it means that in determining the location of new school unit with the distance and time taken by students from the house in less than 45 minutes by foot. In addition, school location points should also be placed within zoning areas that have not yet received educational services especially, in places where population concentration is high, close to the settlements and major roads. The point of new unit location is also strived to be away from the center of the crowds such as shops, offices and industries, so it will not disrupt learning activities. In determining the location of new school units using GIS, can use six parameters, such as land use, topography, settlements, roads, industrial locations, and distribution of schools, then performed GIS analysis (scoring and buffering) and the point of new school units which is in accordance with the standard determination of the location of the school unit will be obtained.

\section{Conclusion}

The importance of Geographic Information Systems (GIS) technology in the determination or selection of new school location is to assist local governments in determining the location of new school units with convenient, accurate, and fast. In addition, the benefits which can be obtained by determining the location of new school unit using Geographic Information System (GIS) for the government is expected to help the policy makers to address the inequality of access to education in the region. While the benefits that obtained by the public is the fulfillment of education services.

\section{References}

Ahmadi dan Indrayati. (2014). Studi Penentuan Lokasi Pembangunan Gedung Sekolah Tingkat Slta Di Kecamatan Tambakromo Kabupaten Pati. Jurnal 'Geo Image (Spatial-Ecological-Regional) 3: 3-4

Aronoff, Stan. (1989). Geographic Information System. Ottawa: WDL Publication.

Jayadinata, T. Johara. (1999). Tata Guna Tanah dalam Perencanaan Pedesaan Perkotaan dan Wilayah. Institut Teknologi Bandung.

Kamsori, Eryk. M. (2007). Penyuluhan dan Pembinaan WAJAR DIKDAS 9 Tahun Sebagai Upaya Peningkatan Mutu Pendidikan dalam Kerangka Peingkatan IPM Jawa Barat. FPIPS UPI

Lampiran Peraturan Menteri Pendidikan Nasional Nomor 24 Tahun 2007 Tanggal 28 Juni 2007 Tentang Standar Sarana Dan Prasarana Sekolah/Madrasah Pendidikan Umum 
Peraturan Menteri Pendidikan Nasional Nomor 24 Tahun 2007 tentang Standar Sarana dan Prasarana untuk SD, SMP, SMA atau sederajat.

Permendikbud Nomor 17 Tahun 2017 Nomor 17 Tahun 2017 tentang Penerimaan Peserta Didik Baru pada Taman Kanak-Kanak, Sekolah Dasar, Sekolah Menengah Pertama, Sekolah Menengah Atas, Sekolah Menengah Kejuruan, atau Bentuk Lain yang Sederajat.

Pranata, M. Nusan. (2014). Pemetaan Lembaga Pendidikan Sekolah Menengah Atas Di Kota Cimahi Melalui Sistem Informasi Geografis. Skripsi : Jururusan Pendidikan Geografi, FPIPS, UPI.

Setiawan, Iwan. (2010). Dasar-dasar Sistem Informasi Geografis. Bandung: Buana Nusantara Press.

Tarigan, Robinson. (2006). Perencanaan Pembangunan Wilayah. Jakarta: Bumi Aksara.

Tim IKIP. (1980). Peran dan Signifikansi Pendidikan.Bandung

UU No.20 Tahun 2003 tentang Sistem Pendidikan Nasional BAB IV pasal 6 ayat 1

Wimardana et al. (2014). Analisa Penentuan Lokasi Pendidikan (Studi Kasus : SMA Komplek Surabaya). Jurusan Perencanaan wilayah dan kota fakultas teknik dan Perencanaan Institut Teknologi Sepuluh Nopember 